Ortaokul Öğrencilerinin Bilişim Teknolojilerinden Yararlanma

Düzeyleri ile Toplumsal Değerlere Yönelik Algıları Arasındaki

\title{
İlişkinin İncelenmesi
}

\section{Examination of the Relationship Between Utilization of Information Technologies Levels and Perceptions for Social Values of Secondary School Students}

\author{
Ayhan KOÇOĞLU (D) 1 , Prof. Dr. Tuğba YANPAR YELKEN (D)2,
}

\author{
Doç. Dr. Sedat KANADLI iD 3
}

\begin{abstract}
$\ddot{\mathbf{O z}}$
$\mathrm{Bu}$ araştırma, ortaokul öğrencilerinin bilişim teknolojilerinden yararlanma düzeyleri ile toplumsal değerlere yönelik algıları arasındaki ilişkinin incelenmesi amacıyla gerçekleştirilmiştir. Araştırma, karma yöntem araştırma desenlerinden açımlayıcı sıralı desen yaklaşımıyla yürütülmüştür. Araştırmanın nicel aşamasında ilişkisel tarama yöntemi kullanılmıştır. Nitel aşamasında ise veriler açık uçlu sorular ile toplanmıştır. Araştırmada nicel veri toplama aracı olarak Özmusul (2011) tarafından geliştirilen "Bilişim Teknolojilerinden Yararlanma Ölçeği" ve Bakaç (2013) tarafindan geliştirilen "Toplumsal Değerlere Yönelik Algı Ölçeği" kullanılmıştır. Nitel veri aracı olarak araştırmacılar tarafından geliştirilen "Bilişim Teknolojileri ve Toplumsal Değerlere Yönelik Öğrenci Görüşme Formu” kullanılmıştır. Araştırmanın örneklemini Mersin ili merkez ilçelerinde öğrenim gören 424 ortaokul öğrencisi oluşturmaktadır. Nicel verilerin analizinde betimsel istatistiklerden yararlanılmış ve korelasyon analizi yapılmıştır. Araştırmanın nitel verileri ise betimsel analiz yöntemi kullanılarak çözümlenmiştir. Nicel verilerin analizi sonucunda ortaokul öğrencilerinin bilişim teknolojilerinden daha çok iletişim kurma ve araştırma yapma amaçlı faydalandıkları ortaya çıkmıştır. Bununla birlikte öğrencilerin toplumsal değerlere yönelik algılarının ise daha çok olumlu yönde olduğu belirlenmiştir. Ayrıca öğrencilerin biliş̧im teknolojilerinden yararlanma düzeyleri ile toplumsal değerlere yönelik algıları arasında anlamlı bir ilişki bulunamamıştır. Nitel veri analizi sonucunda ise öğrencilerin bilişim teknolojilerinden bilgi edinme, araştırma-inceleme yapma ve oyun-eğlence amaçlı yararlanırken toplumsal değerleri dikkate almadıkları belirlenmiştir.
\end{abstract}

Anahtar Kelimeler: Bilişim teknolojileri, değerler, ortaokul öğrencileri

Makale Türü: Araştırma

\begin{abstract}
The aim of this study was to examine the relationship between the level of secondary school students' use of information technologies and their perceptions of social values. The study was conducted through exploratory sequential mixed method research design. In the quantitative phase of the study, relational screening method was used. In the qualitative phase, data were collected through open-ended questions. In this study, "Utilization of Information and Communication Technologies Scale" developed by Özmusul (2011) and "The Perception Scale for Social Values" developed by Bakaç (2013) were used as
\end{abstract}

${ }^{1}$ Mersin Üniversitesi, Eğitim Fakültesi, ayhan526@hotmail.com.

${ }^{2}$ Mersin Üniversitesi, Eğitim Fakültesi, tyanpar@gmail.com.

${ }^{3}$ Mersin Üniversitesi, Eğitim Fakültesi, skanadli@mersin.edu.tr.

Atıf için (to cite): Koçoğlu, A., Yanpar Yelken, T. ve Kanadlı, S. (2020). Ortaokul öğrencilerinin bilișim teknolojilerinden yararlanma düzeyleri ile toplumsal değerlere yönelik algıları arasındaki ilişkinin incelenmesi. Afyon Kocatepe Üniversitesi Sosyal Bilimler Dergisi,22(2), 399-417. 
quantitative data collection tools. "The Student Opinion Form for Information Technologies and Social Values" developed by the researchers was used as a qualitative data tool. The sample of the study consisted of 424 secondary school students whose studying in the central districts of Mersin. Descriptive statistics were utilized, and correlation analysis was conducted in the analysis of quantitative data. Qualitative data of the research were analyzed through descriptive analysis method. As a result of the quantitative data analysis, it was determined that secondary school students were mostly use information technologies in order to communicate and conduct research. In addition, there was no significant relationship between students' level of using information technologies and their perceptions about social values. As a result of qualitative data analysis, it was determined that the students did not take into consideration social values while using information technologies, making research-examination and playing-entertainment.

Keywords: Information technologies, social values, secondary school students

Paper Type: Research

\section{Giriş}

Bilgi gerek bireyler gerek toplumlar için hayatın her alanında yaşanan gelişimlere ayak uydurabilme noktasında geçmişten günümüze dek ihtiyaç duyulan önemli zenginliklerden biri olmuştur. Bilgiye ulaşma ve bilgiyi paylaşma hususu ise zamandan bağımsız olarak her daim değerli olsa da 21. yüzyıl bu konuda bir sıçrama tahtası niteliği taşımaktadır. Zira bu çağda bilim ve teknoloji alanlarında yaşanan gelişmeler günlük hayata etkili bir şekilde sirayet etmiş, bireylerin teknolojiye ve teknolojik araçlara erişme imkânını artırmıştır. Böylece internet, bilgisayar ve hatta bilgisayar özelliği taşıyan cep telefonlarının kullanımı ile bilginin elektronik ortamda kolay ve hızlı bir şekilde iletilebilmesi sağlanmıştır. Tüm bu gelişmeler bilgi çağının doğuşuna zemin hazırlamış, bilgiyi ve teknolojiyi buluşturan "bilişim teknolojisi" kavramını ortaya çıkarmıştır.

Günümüzde bilişim teknolojileri, genel olarak bilginin elektronik olarak elde edilmesini, işlenmesini, görüntülenmesini ve iletilmesini kolaylaştıran ekipman ve hizmetleri kapsar (Torero ve Von Braun, 2006). Bilgi ve iletişim teknolojilerinin yayılması ve yaygınlaştırılması ile insan faaliyetlerinin her alanında görülen değişiklikler baş döndürücü bir hıza ulaşmıştır. Bu hızlı değişim sürecinden eğitimin de payına düşeni aldığını ifade etmek gereklidir. Nitekim bilgi üretebilen bir toplumun yetiştirilmesinde teknoloji oldukça önemli bir yer tutmaktadır ve bu süreçte yeni teknolojilerin kullanılması bir zorunluluk haline gelmiştir (Erişen ve Çeliköz, 2007).

Bilişim teknolojileri günümüz bilgi toplumlarının vazgeçilmez bir uzantısı olmakla birlikte insanlara pek çok yarar sağlamaktadır (Çalık ve Çınar, 2009). Bilişim teknolojilerinin kullanımı, öğrencilerin hem iş birliği hem de bağımsız olarak çalışmalarına olanak sağlayarak takım ruhuna uygun hareket etmelerine, bulundukları ortama uyum sağlamalarına ve sosyal değerleri geliştirmelerine yardımcı olmaktadır (Khirwadkar, 2007). Bununla birlikte öğrencilerin üst düzey düşünme becerilerini geliştirmekte (Hopson, Simms ve Knezek, 2001); öğrenmelerini desteklemekte (Vannatta, Beyerbach ve Walsh, 2001); kendi çalışmalarının sorumluluğunu almalarını sağlamaktadır (Turney, Robinson ve Soutar, 2009).

Bilişim teknolojilerinin olumlu etkilerinin yanında olumsuz etkileri de bulunmaktadır. Chu'ya (2014) göre, doğru yönlendirme olmaksızın öğrencilerin mobil teknolojik araçları kullanmaları öğrenme başarılarını olumsuz etkilemektedir. Buna paralel olarak Aktaş, Alioğlu ve Vardar (2007), yaptıkları bir çalışmada öğrencilerin bilişim teknolojilerini kullanma zamanı arttıkça not ortalamalarının düştüğünü belirtmişlerdir. Denizci (2009) kişilerin bilgisayar teknolojilerini kullanarak daha çok zaman harcadığını ve zamanının çoğunu yalnız geçirmekte olduğunu ileri sürmektedir. Çalık ve Çınar (2009) ise bilgiye ulaşmada hız ve kolaylık sağlayan bilişism teknolojilerinin kişileri tembelleştirdiğini ifade etmektedir. Bilişim teknolojilerinin neden olduğu bu olumsuzlukların toplumsal ve bireysel anlamdaki etkilerini azaltabilmek için 
toplumların kültürel farklılıklarını özümseyerek sürdürebilmesi gerekmektedir (Çalık ve Çınar, 2009). Çünkü toplumların varlıklarını sürdürebilmeleri, sahip olunan değerlerin yeni nesillere aktarımı ile mümkün olabilir (Çubukçu, Eker Özenbaş, Çetintaş, Satı ve Yazlık Şeker, 2012). $\mathrm{Bu}$ ifadeler göz önüne alındığında teknolojinin olumsuz etkilerini azaltmada kültürel farklılıkların özümsenerek sürdürülmesi ve değerlerin gelecek nesillere aktarımının önemli olduğu söylenebilir.

\section{Değer Kavramı ve Bilişim Teknolojileri}

Değer kavramı felsefe, psikoloji, sosyoloji, antropoloji ve hatta ekonomi gibi çeşitli alanların konusu olmakla birlikte değerlere ilişkin ortak bir tanımda bulunmak mümkün görünmemektedir. Bununla birlikte genel olarak değerler, düşünce ve eylemlerimizi etkileyerek onlara yön veren zihinsel olgular şeklinde tanımlanabilir (Demircioğlu ve Tokdemir, 2008). Platon'dan bu yana değerlerin çok çeşitli açılardan sınıflandırıldığı görülmekle birlikte bu sınıflandırmada da bir fikir birliğinin olmadığı söylenebilir. Bunlara örnek olarak, Platon değerleri ahlaki ve estetik değerler olarak ikiye ayırmış (Sönmez, 2012); Spranger değerleri “ Sosyal", "Teorik", "Ekonomik", "Politik", "Dini"ve "Estetik" olmak üzere alt1 grup altında toplamış (Spranger, 2001), Rokeach değerleri amaç değerler ve araç değerler olarak iki grup altında sınıflandırmış (Rokeach, 1973); Schwartz değerleri Schwartz Değerler Envanteri'nde çeşitli açılardan 10 grup altında toplamıştır (Schwartz, 1996). Değerlerin sınıflandırılması ülkemizdeki öğretim programlarında ise "kök değerler" kavramı olarak yer almış ve bu programlarda dokuz ayrı kök değerin bulunduğu vurgulanmıştır (MEB, 2018). Bu kök değerler; adalet, dostluk, dürüstlük, öz denetim, sabır, saygı, sevgi, sorumluluk, vatanseverlik ve yardımseverliktir. Eğitim sisteminin bu kök değerleri kazandırma amacı çerçevesindeki işlevi, öğretim programlarını da kapsayan eğitim programılla yerine getirilmektedir (MEB, 2018). Son olarak 2017-2018 eğitim/öğretim yılında değişen yeni öğretim programlarında değerlerin ve değerler eğitiminin programların odağında yer aldığı görülmektedir (MEB, 2018). Buna göre tüm öğretim programlarında "Temel insani özelliklerimizi oluşturan değerlerimiz, öğretim programlarının perspektifini oluşturan ilkelerin toplamıdır" ifadesine yer verilmiş, "Bütün eğitim sürecinin nihai gayesi ve ruhu olan değerlerimiz, ögretim programlarının her birinde ve her bir biriminde yer almıştır" denilmiştir. Değerler gibi bilişim teknolojileri de eğitimin her alanında yer almaktadır. Bu iki kavram arasındaki ilişkinin ortaya konulması bakımından bilişism teknolojilerinin öğretim programlarındaki işlevini anlamak önemlidir.

Bilişim teknolojilerinin öğretim programı içindeki rolü sadece öğrencilerin öğrenme deneyimlerini artırmak değil, aynı zamanda gelecekte onların iş dünyasına etkin bir şekilde katılımları için gerekli olan becerileri geliştirmelerine de yardımcı olmaktır (Khirwadkar, 2007). Bilişim teknolojilerinin etkili, olumlu ve istenilen şekilde kullanılabilmesi için bireylerin bir takım yeni beceriler kazanması gerekmektedir (Çalık ve Çınar, 2009). Nitekim son yıllarda dünyada ve Türkiye'de meydana gelen bilimsel, teknolojik ve sosyal gelişmeler toplumlarda da geleceğin insanlarında bulunması gereken becerilerin farklılaşmasına neden olmuştur. Bunun eğitime bir yansıması olarak yetiştirilecek insanlarda bulunması gereken yeterlilikler Avrupa Yeterlilikler Çerçevesi kapsamında tanımlanmış, tanımlanan bu yeterliliklere Türkiye Yeterlilikler Çerçevesinde de yer verilmiştir (MEB, 2018). Bu bağlamda yenilenen öğretim programlarında 21. Yüzyıl becerileri olarak da anılan dokuz temel beceriden bahsedilmektedir. Bahsedilen beceriler arasında "bilim ve teknoloji yeterliliği" ile "dijital yeterlilik" de bulunmaktadir.

Bilişim teknolojilerinin eğitimde kullanılması ve değerlere ilişkin alanyazın incelendiğinde ortaokul öğrencilerinin bilişim teknolojilerinden yararlanma düzeyleri (Tor ve Erden, 2004; Cab1, Erden ve Kırkan, 2016; Arabac1, 2012; Özmusul, 2008) ve toplumsal değerlere yönelik algıları (Ergün Kaplan ve Sulak, 2017; Bakaç, 2013) ile ilişkili ayrı ayrı farklı değişkenler üzerinde yapılan çalışmaların olduğu görülmektedir. Öte yandan öğrencilerin bilişim teknolojilerini kullanma düzeyleri ile toplumsal değerlere ilişkin algıları arasındaki ilişkiyi belirlemeye yönelik bir çalışma bulunmamaktadır. Ancak teknoloji ve değerler 
bağlamında çeşitli çalışmalara rastlanılmaktadır. Srite ve Karahanna'nın (2006) teknolojinin kabulünde ulusal kültürel değerlerin rolünü ortaya çıkarmayı amaçladıkları çalışma; Mukti ve Hwa’nın (2004) ahlaki değerlerin öğretimi için interaktif çoklu medya öğrenme ortamlarının geliştirilmesini amaçladıkları çalışma ve Ohler' in (2011) dijital çağda karakter eğitimine ilişkin çalışmaları buna örnek olarak verilebilir. Bu açıdan bakıldı ̆̆ında çalışmanın, yenilenen öğretim programlarında da önemli yer tutan teknoloji ve değerler arasındaki ilişkiyi ortaya koyması ve bu iki konunun birbiriyle olan ilişkisine yönelik bir çalışmaya rastlanamaması nedeniyle alana katkı sağlayacağı düşünülmektedir.

Bu bağlamda çalışmanın amac1, 2017/2018 eğitim öğretim yılında Mersin ilinde öğrenim gören ortaokul öğrencilerinin bilişim teknolojilerinden yararlanma düzeyleri ile toplumsal değerlere ilişkin algıları arasındaki ilişkinin incelenmesidir. Bu nedenle çalışmanın problem cümlesi "Ortaokul öğrencilerinin bilişim teknolojilerinden yararlanma düzeyleri ile toplumsal değerlere ilişkin algıları arasındaki ilişki nedir?" şeklinde belirlenmiştir. Bu temel probleme dayalı olarak çalışmanın alt problem cümleleri şöyle sıralanabilir: Ortaokul öğrencilerinin;

1. Bilişim teknolojilerinden yararlanma düzeyi nasıldır?

2. Toplumsal değerlere yönelik algıları nasıldır?

3. Bilişim teknolojilerinden yararlanma düzeyi ile toplumsal değerlere yönelik algıları arasındaki ilişki nedir?

4. Bilişim teknolojilerinden yararlanma ve toplumsal değerlere yönelik algıları arasındaki ilişkiye yönelik görüşleri nelerdir?

\section{Yöntem}

$\mathrm{Bu}$ çalışma genel tarama modellerinden ilişkisel tarama modeline göre yapılandırılmıştır. İlişkisel tarama modeli iki değişken arasında bir ilişki olup olmadığını, eğer ilişki var ise derecesini belirlemek amaciyla kullanılan bir modeldir (Karasar, 2017, s. 114). Veri toplama yöntemi olarak karma araştırma desenlerinden biri olan "açımlayıcı sıralı desen" kullanılmıştır. "Açımlayıcı sıralı desen" kullanılarak yapılan çalışmalarda önce nicel veriler toplanıp çözümlenerek nitel verilerle açllanmaya ihtiyaç duyulan sonuçlar belirlenir. Daha sonra bu sonuçları açıklamak için nitel veriler toplanıp analiz edilerek nicel bulguları açıklayacak bir yapı ortaya çıkarılır (Creswell \& PlanoClark, 2015, s. 92). Bu çalışmada öğrencilerin bilişim teknolojilerinden yararlanma düzeyleri ile toplumsal değerlere ilişkin algıları arasındaki ilişkinin daha iyi anlaşılmasını sağlamak amacıyla karma yöntem tercih edilmişsir. Araştırmaya ilişkin şematik desen Şekil 1'de gösterilmiştir.

Şekil 1. Araştırma deseninin şematik gösterimi

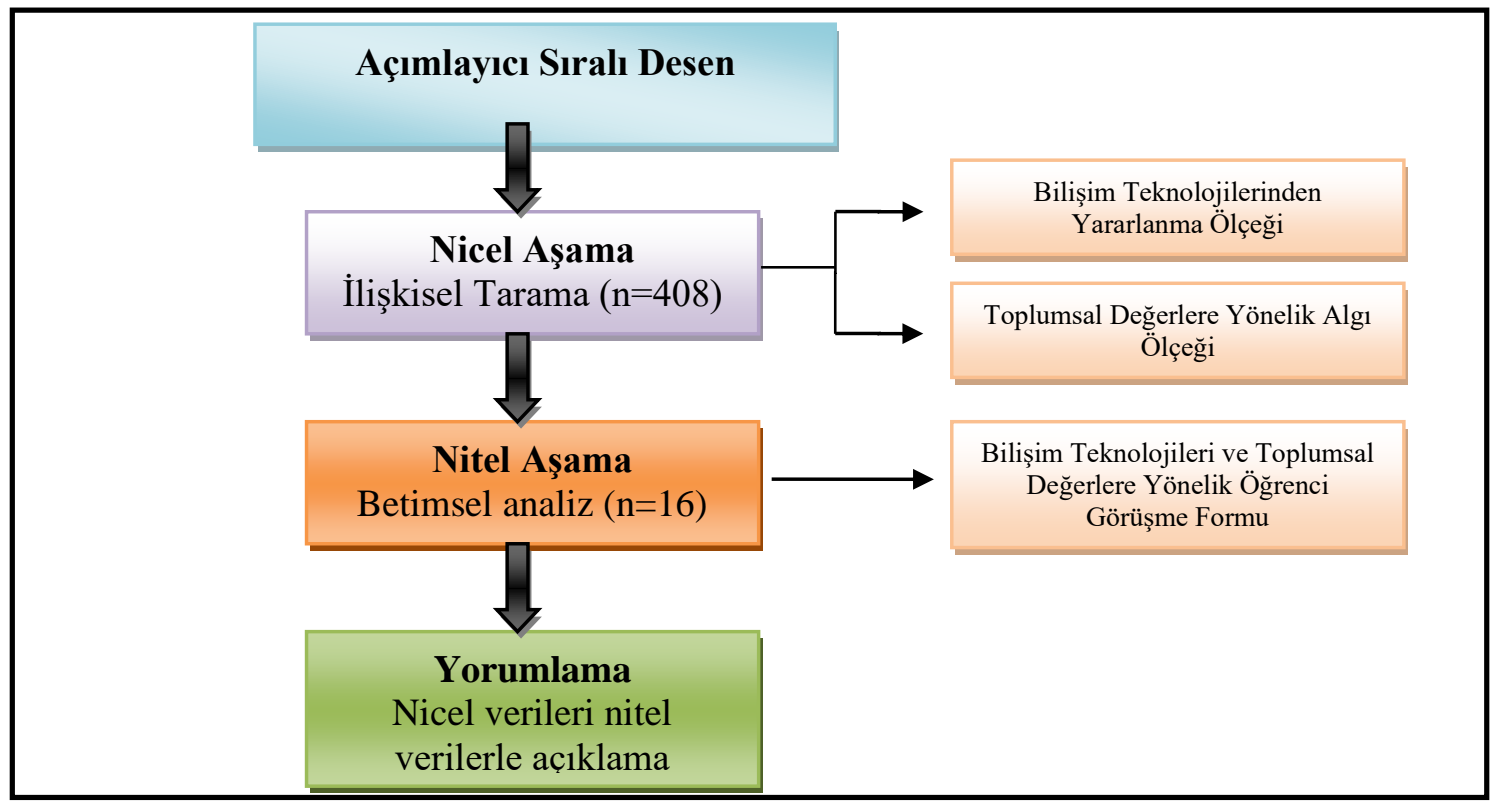




\subsection{Evren ve Örneklem}

Araştırmanın genel evreni Mersin İlinde öğrenim gören tüm ortaokul öğrencileridir. $\mathrm{Bu}$ evreni oluşturan öğrenci sayıs1 40.846' dır. Aypay'ın (2015), örnekleme büyüklüğü ile güven aralıklarını gösterdiği tabloya göre 40000 kişilik bir evrenden $\% 95$ güven aralığı ve $\% 3$ sapma miktarıyla 380 kişilik bir örneklem büyüklüğünü yeterli görmektedir. Bu nedenle araştırmanın örneklemini Mersin ili merkez ilçelerindeki ortaokullarda öğrenim gören 408 öğrenci oluşturmaktadır. Örneklemi oluşturan öğrenciler, küme örnekleme yöntemlerinden biri olan oransız küme örneklem yöntemi ile belirlenmiştir. Oransız küme örneklem yöntemi, evrendeki tüm kümelerin (okullar ve sınıflar) birbirine eşit seçilme şansına sahip oldukları örnekleme türüdür (Karasar, 2017). Bu örnekleme yöntemi, çalış1lması düşünülen evrende doğal olarak oluşmuş veya farklı amaçlarla yapay olarak oluşturulmuş, kendi içinde belirli özellikler açısından benzerlik gösteren değişik grupların oluşması durumunda kullanılır (Yıldırım ve Şimşek, 2008). Çalışmada her bir okulun küme olarak görülmesi ve bu kümelerin evrende doğal olarak oluşması (araştırmacının müdahalesi olmaksızın) nedeniyle bu örnekleme yöntemi seçilmiştir. Araştırmaya katılan öğrencilerin demografik bilgileri tablo 1'de sunulmuştur.

Tablo 1. Katılımcı öğrencilere ilişkin demografik bilgiler tablosu

\begin{tabular}{lcccccccccc}
\hline & \multicolumn{2}{c}{ 5.Sınıf } & \multicolumn{2}{c}{ 6.Sınıf } & \multicolumn{2}{c}{ 7.Sınıf } & \multicolumn{2}{c}{ 8.Sınıf } & \multicolumn{2}{c}{ Toplam } \\
\hline & $\mathrm{f}$ & $\%$ & $\mathrm{f}$ & $\%$ & $\mathrm{f}$ & $\%$ & $\mathrm{f}$ & $\%$ & $\mathrm{f}$ & $\%$ \\
Kadın & 26 & 49 & 67 & 46.8 & 55 & 48.6 & 50 & 50 & 198 & 48.5 \\
Erkek & 27 & 51 & 76 & 53.2 & 58 & 51.4 & 49 & 50 & 210 & 51.5 \\
Toplam & 53 & 100 & 143 & 100 & 113 & 100 & 99 & 100 & 408 & 100 \\
\hline
\end{tabular}

Tablo 1'e göre araştırmaya katılan öğrencilerin 198'i (\%48.5) kadın, 210'u (\%51.5) erkektir. Yine aynı tabloya göre araştırmaya katılan öğrencilerin 53'ünün (\%13) beşinci sınıfta, 143'ünün (\%35) altıncı sınıfta, 113'ünün (27.7) yedinci sınıfta ve 99'unun (\%24.3) ise sekizinci sınıfta öğrenim görmekte olduğu anlaşılmaktadır.

Araştırmada nitel verilerin toplandığı grubun belirlenmesinde amaçlı örnekleme yöntemlerinden biri olan maksimum çeşitlilik örnekleme yöntemi kullanılmıştır. Bu yöntem araştırma sürecinin başlangıcında yer alan farklılıkların ve çeşitli bakış açılarının maksimum derecede yansıtılmasının amaçladığı nitel çalışmalarda sıklıkla kullanılmaktadır (Creswell, 2007, s. 126). Mevcut araştırmada sınıf düzeyi ve cinsiyet değişkenleri çeşitlilik kaynağı olarak ele alınmıştır. Bu nedenle araştırmanın nitel çalışma grubu, her sınıf düzeyinden iki kız ve iki erkek öğrenci olmak üzere dört sınıf düzeyi için toplamda 16 öğrenciden oluşmaktadır. Katılımcı gizliliğini korumak amacıyla araştırmada yer alan her bir öğrenciye ayrı kod isim verilmiştir. Çalışma grubunda yer alan katılımcılara ilişsin bazı bilgiler tablo 2'de görülmektedir.

Tablo 2. Nitel verilerin toplandığı öğrencilere ilişkin demografik bilgiler tablosu

\begin{tabular}{|c|c|c|}
\hline Kod isim & Cinsiyet & Sinif \\
\hline Ahmet & Erkek & 5.sinif \\
\hline Mehmet & Erkek & 5.sinif \\
\hline Arzu & Kadın & 5.sinif \\
\hline Yusuf & Erkek & 5.sinif \\
\hline Musa & Erkek & 6.sinif \\
\hline Hatice & Kadın & 6.sinif \\
\hline Ayşe & Kadın & 6.sinif \\
\hline Zeynep & Kadın & 6.sinif \\
\hline Hasan & Erkek & 7.sinif \\
\hline Zümrüt & Kadın & 7.sinif \\
\hline Sevim & Kadın & 7.sinif \\
\hline
\end{tabular}




\begin{tabular}{lll}
\hline Süreyya & Kadın & 7. sinıf \\
Elif & Kadın & $8 . \sin ı f$ \\
Burak & Erkek & $8 . \sin ı f$ \\
Aziz & Erkek & 8. sinıf \\
Defne & Kadın & $8 . \sin ı f$ \\
\hline
\end{tabular}

\subsection{Veri Toplama Araçları}

Araştırmanın nicel verileri Özmusul (2011) tarafından geliştirilen "Bilişsim Teknolojilerinden Yararlanma Ölçeği" ile Bakaç (2013) tarafindan geliştirilen "Toplumsal Değerlere Yönelik Algı Ölçeği” kullanılarak toplanmıştır. Bu ölçeklerin başında öğrencilerin demografik bilgilerinin yer aldığı kişisel bilgi formu da bulunmaktadır. Araştırmanın nitel verileri ise araştırmacılar tarafından oluşturulan yarı yapılandırılmış görüşme formu aracılığı ile toplanmıştır. Sayılan veri toplama araçlarına ilişkin bilgiler aşağıda yer almaktadır.

Kişisel Bilgi Formu: Ortaokul öğrencilerinin cinsiyet, yaş, sınıf düzeyi ve akademik başarılarına ilişkin demografik bilgileri araştırmacılar tarafından oluşturulan kişisel bilgi formu kullanılarak elde edilmiştir. $\mathrm{Bu}$ form eğitim programları ve öğretim alanında uzman iki araştırmacının görüşü alındıktan sonra uygulanmıştır.

Bilişim Teknolojilerinden Yararlanma Ölçeği: Araştırmada ortaokul öğrencilerinin bilişim teknolojilerinden yararlanma düzeylerini saptamak için kullanılan bu ölçek, yine aynı amaçla Özmusul (2011) tarafından geliştirilmiştir. Toplamda 18 maddeden oluşan ölçek "Hiçbir zaman" ile "Her zaman" arasındaki seçeneklerin yer aldığı 4'lü likert tipte hazırlanmıştır. Ölçekten alınabilecek en düşük puan 18; en yüksek puan ise 72 'dir. Ölçek bilgi edinme, araştırma-inceleme, iletişim, oyun-eğlence ve kendini ifade etme olarak adlandırılan beş faktörden oluşmaktadır. Ölçeğin Cronbach Alpha değeri .857 olarak hesaplanmıştır (Özmusul, 2011). Bu çalışmaya ilişkin Cronbach Alpha değeri .837 bulunmuştur.

Toplumsal Değerlere Yönelik Algı Ölçeği: Araştırmada kullanılan bu ölçek Bakaç (2013) tarafindan ortaokul 5.sınıf öğrencilerinin toplumsal değerlere yönelik algılarının belirlenmesi amacıyla geliştirilmiştir. İki faktörden oluşan ölçekte 23 madde bulunmakla birlikte bu maddeler için belirlenen seçenekler "kesinlikle katılmıyorum", "katılmıyorum", "kararsızım", "katılıyorum" ve "kesinlikle katılıyorum" şeklinde ifade edilmiştir. Ölçekten alınabilecek minimum puan 23; maksimum puan ise 115'tir.Ölçeğin Cronbach Alpha değeri .86 olarak hesaplanmıştır (Bakaç, 2013). Bu araştırmada ise Cronbach Alpha değeri .824 olarak hesaplanmıştır.

Bilişsim Teknolojileri ve Toplumsal Değerlere Yönelik Öğrenci Görüşme Formu: Bu form araştırmacılar tarafindan ortaokul öğrencilerinin bilişim teknolojilerinden yararlanma düzeyleri ile toplumsal değerlere yönelik algılarına ilişkin görüşlerini ortaya çıkarmak amacıyla yarı yapılandırılmış sorulardan oluşturulmuştur. Görüşme formu oluşturulurken ilgili alanyazın incelenmiştir. Bu doğrultuda araştırmanın amacına uygun beş soruluk bir taslak görüşme formu hazırlanmıştır. Hazırlanan taslak görüşme formu bilişim teknolojileri, eğitim programları ve öğretim ile değerler eğitimi üzerine çalışan dört ayrı uzman tarafindan incelenmiştir. Uzmanlardan elde edilen görüş, tavsiye ve düzeltmeler doğrultusunda gerekli düzenlemeler yapılmıştır. Daha sonra taslak görüşme formu ile çalışma grubu dışındaki dört öğrenci üzerinde pilot uygulama yapılmış ve elde edilen dönütler çerçevesinde görüşme formu son şekline getirilmiştir. $\mathrm{Bu}$ formda yer alan ve bilişim teknolojilerinden yararlanma ölçeğinin alt boyutlarına göre oluşturulan sorular şunlardır;

1. Bilişim Teknolojilerini (bilgisayar, internet, cep telefonu vb.) herhangi bir konuda bilgi edinmek amacıyla kullanırken toplumsal değerlere (dürüstlük, adalet, saygı, sevgi, sorumluluk, barış, özgürlük, hoşgörü, yardımseverlik, duyarlılık, dayanışma, bilimsellik, sağlık, temizlik, estetik) dikkat eder misin? Neden? 
2. Bilişim Teknolojilerini kullanarak bir konu hakkında araştırma inceleme yaparken (örneğin proje ödevlerini yapmak için kullanırken) toplumsal değerlere dikkat eder misin? Neden?

3. Bilişim Teknolojilerini kullanarak insanlarla iletişim kurarken toplumsal değerlere dikkat eder misin? Neden?

4. Bilişim Teknolojilerini oyun oynamak ve eğlenmek amacıyla kullanırken toplumsal değerlere dikkat eder misin? Neden?

5. Bilişim Teknolojilerini kullanarak düşüncelerini ifade ederken (örneğin sosyal medyada bir fikrini paylaşmak gibi) toplumsal değerlere dikkat eder misin? Neden?

Araştırmanın nitel verileri için her sınıf düzeyinde bir tane olmak üzere toplamda dört grup oluşturulmuştur. Öğrenciler ile grup halinde yapılan yüz yüze görüşmeler esnasında görüşme formu aracılı̆̆ 1 ile nitel veriler elde edilmiştir. Araştırmacılar tarafindan görüşme formunda yer alan sorulara ilişkin ön bilgiler verilmiş ve ayrıntılı açıklamalar yapılmıştır. Bu açıklamaların ardından katılımcılardan görüşme formunda yer alan sorulara ilişkin cevap yazmaları sağlanmıştır. Her bir görüşme ortalama 20-30 dakika sürmüştür.

\subsection{Verilerin Analizi}

Araştırma verilerinin analizinden önce araştırmada yer alan her bir değişkenin normal dağılım gösterip göstermediğini belirlemek için Kolmogorov-Smirnov normallik testi uygulanmıştır. Normallik testi sonucunda tüm değişkenlere ilişkin veriler normal dağ 11 ım gösterdiğinden ( $p>0.05)$ araştırmanın nicel verileri için parametrik testler kullanılmıştır.

Araştırmada ortaokul öğrencilerinin bilişim teknolojilerinden yararlanma düzeyi ve toplumsal değerlere yönelik algılarının nasıl olduğunu belirleyebilmek için betimsel istatistiklerden yararlanılmıştır. Bunun için orijinal ölçeklerde yer alan puan aralıkları göz önünde bulundurulmuştur. Bilişim Teknolojilerinden Yararlanma Ölçeği’ne göre puanlar ve yararlanma düzeyleri şu şekilde değerlendirilmiştir;

1-1,75 puan aralığında; Yararlanma yok,

1,76-2,50 puan aralığında; Düşük,

2,51-3,25 puan aralığında; Orta,

3,26-4,00 puan aralığında ise; Yüksek (Özmusul, 2008).

Öğrencilerinin bilişim teknolojilerinden yararlanma düzeyi ile toplumsal değerlere yönelik algıları arasında anlamlı bir ilişki olup olmadığını belirleyebilmek için korelasyon analizi yapılmıştır. Araştırmanın nitel verileri ise betimsel analiz yöntemi kullanılarak çözümlenmiştir. Betimsel analiz yönteminde veriler daha önceden belirlenen ya da araştırma sorularının ortaya koyduğu temalara göre düzenlenerek özetlenmekte ve yorumlanmaktadır (Yıldırım ve Şimşek, 2008). Yarı yapılandırılmış görüşme formlarından elde edilen veriler analiz edilirken öğrencilerin bilişim teknolojilerinden yararlanma düzeylerine ilişkin bir alan yazının olduğu ve araştırma sorularının belirli bir tema ortaya koyması nedeniyle betimsel analiz yöntemi kullanılmıştır. Yıldırım ve Şimşek (2008) betimsel analiz yönteminin; betimsel araştırma için bir çerçeve oluşturma, tematik çerçeveye göre verilerin işlenmesi, bulguların tanımlanması ve son olarak bulguların yorumlanması olmak üzere dört aşamadan oluştuğunu belirtmektedir. Bu çalışmada da betimsel analiz sırasında bu aşamalar takip edilmiştir. Betimsel analizin ilk adımında var olan kavramsal çerçeve ve araştırma soruları göz önünde bulundurularak veri analizi için tematik bir çerçeve oluşturulmuştur. Daha sonraki adımda elde edilen veriler okunmuş, anlamlı ve mantıklı bir biçimde bir araya getirilerek grafiklerle ifade edilebilecek şekilde düzenlenmiştir. Bunu takip eden adımda ise düzenlenen grafiklerde yer alan veriler doğrudan alıntılarla desteklenerek tanımlanmış ve son olarak tanımlanan bulgular yorumlanmıştır. 
Araştırmada nitel verilerin güvenirliğini sağlamak amacıyla görüşme formlarından elde edilen veriler iki farklı uzman tarafından ayrı ayrı kodlanmıştır. Kodlama sonucu görüş birliğine varılan ve varılmayan kodlar belirlenerek kodlayıcılar arası güvenirlik yüzdesi hesaplanmıştır. Güvenirlik hesaplanırken Miles ve Huberman (1994)'ın görüş birliğine varılan kodlar/(görüş birliğine varılan kodlar + görüş ayrılı̆̆ı olan kodlar) X 100 formülünden yararlanılmıştır. $\mathrm{Bu}$ formüle göre kodlayıcılar arası güvenirlik $((70 / 68+8)$ X100) \%92 olarak bulunmuştur. Kodlayıcılar arası güvenirliğin $\% 70$ ve üzerinde olduğu durumlarda yeterli bir güvenirlik değerinin sağlandığ 1 ileri sürülmektedir (Miles ve Huberman, 1994). Araştırmada hesaplanan yüzde göz önünde bulundurulduğunda kodlamaların yeterli düzeyde güvenilir olduğu söylenebilir.

\section{Bulgular ve Tartışma}

$\mathrm{Bu}$ bölümde elde edilen bulgular, araştırma soruları göz önünde bulundurularak özetlenmiştir.

\subsection{Ortaokul Öğrencilerinin Bilişim Teknolojilerinden Yararlanma Düzeyleri Nasıldır?}

Ortaokul öğrencilerinin bilişim teknolojilerinden yararlanma düzeylerinin nasıl olduğunu belirleyebilmek için Bilişim Teknolojilerinden Yararlanma Ölçeğinden aldıkları puanların ortalamalarına bakılmıştır. Elde edilen sonuçlar tablo 3'te verilmiştir.

Tablo 3. Bilişim teknolojilerinden yararlanma ölçeğine ilişkin betimsel istatistik sonuçları

\begin{tabular}{lccccc}
\hline Ölçeğin Boyutları & $\mathbf{N}$ & $\begin{array}{c}\text { En } \\
\text { Küçük }\end{array}$ & $\begin{array}{c}\text { En } \\
\text { Büyük }\end{array}$ & $\overline{\boldsymbol{X}}$ & Ss \\
\hline Bilgi edinme & & 1 & 4 & 2.7 & .58 \\
Araştırma & 408 & 1 & 4 & 3 & .68 \\
İletişim & & 1 & 4.2 & 3.1 & .75 \\
Oyun-eğlence & & 1 & 4 & 2.5 & .90 \\
Kendini ifade etme & & 1.06 & 3.89 & 2.75 & .77 \\
Genel Ortalama & & & \\
\hline
\end{tabular}

Tablo 3'e bakıldığında öğrencilerin Bilişim Teknolojilerinden Yararlanma ölçeğinin tüm alt boyutlarına göre genel ortalama puanlarının $(\bar{X}=2.75)$ orta düzeyde olduğu görülmektedir. Ölçeğin bilgi edinme alt boyutuna ilişkin genel ortalamanın $(\bar{X}=2.7)$; araştırma alt boyutuna ilişkin genel ortalamanın $(\bar{X}=3)$; iletişim alt boyutuna ilişkin genel ortalamanın $(\bar{X}=3.1)$ ve oyun-eğlence alt boyutuna ilişkin ortalamanın $(\bar{X}=2.5)$ orta düzeyde olduğu belirlenmiştir. Bunun yanında tablo 4'e göre kendini ifade etme alt boyutunda genel ortalama $(\bar{X}=2)$ düşük düzeydedir. Bu bulgu ortaokul öğrencilerinin bilişim teknolojilerini daha çok iletişim kurma ve araştırma yapma amacıyla kullandıkları şeklinde yorumlanabilir.

\subsection{Ortaokul Öğrencilerinin Toplumsal Değerlere Yönelik Algıları Nasıldır?}

Ortaokul öğrencilerinin toplumsal değerlere yönelik algılarının nasıl olduğunu belirleyebilmek için Toplumsal Değerlere Yönelik Alg1 Ölçeğinden aldıkları puanların ortalamaları incelenmiştir. Ölçekten elde edilen sonuçlar tablo 4'te verilmiştir.

Tablo 4. Toplumsal değerlere yönelik algı ölçeğine ilişkin betimsel istatistik sonuçları

\begin{tabular}{lccccc}
\hline Ölçeğin Boyutları & $\mathbf{N}$ & $\begin{array}{c}\text { En } \\
\text { Küçük }\end{array}$ & $\begin{array}{c}\text { En } \\
\text { Büyük }\end{array}$ & $\overline{\boldsymbol{X}}$ & Ss \\
\hline $\begin{array}{l}\text { Toplumsal Değerlere Yönelik Olumlu Algılar } \\
\text { Toplumsal Değerlere Yönelik Olumsuz }\end{array}$ & 408 & 1.11 & 5 & 4.24 & .55 \\
$\begin{array}{l}\text { Algılar } \\
\text { Genel Ortalama }\end{array}$ & & 5 & 2.29 & 1.11 \\
\hline
\end{tabular}

Tablo 4'te yer alan bilgiler incelendiğinde olumlu algılar alt boyutundaki ortalama puanların $(\bar{X}=4.24)$ daha yüksek olduğu görülmektedir. Bunun yanında ortalama puanlar göz önünde bulundurulduğunda en düşük puanların $(\bar{X}=2.29)$ "Toplumsal Değerlere Yönelik 
Olumsuz Algılar" alt boyutunda yer aldığı anlaşılmaktadır. Bu bulgulara göre ortaokul öğrencilerinin toplumsal değerlere yönelik algılarının daha çok olumlu yönde olduğu ileri sürülebilir.

\subsection{Ortaokul Öğrencilerinin Bilişim Teknolojilerinden Yararlanma Düzeyi İle Toplumsal Değerlere Yönelik Algıları Arasında Anlamı Bir İlişki Var Mıdır?}

$\mathrm{Bu}$ araştırma sorusuna yanıt bulabilmek için araştırmada yer alan iki değişkene ilişkin Pearson Momentler Çarpım Korelasyon katsayısı hesaplanmıştır. Ortaya çıkan sonuçlar tablo 5'te verilmiştir.

Tablo 5. Bilişim teknolojilerinden yararlanma ile toplumsal değerlere yönelik algı arasındaki iliş̧ki

\begin{tabular}{lccc}
\hline & & TDYA Ölçeği & \\
BTYÖ Boyutları & $\mathbf{N}$ & $\mathbf{r}$ & $\mathbf{p}$ \\
\hline Bilgi Edinme & & .077 & .122 \\
Araştırma İnceleme & & .003 & .958 \\
İletişim & 408 & .026 & .595 \\
Oyun-Eğlence & & .060 & .228 \\
Kendini İfade Etme & & .000 & .995 \\
\hline
\end{tabular}

$p<.005$

Tablo 5'te yer alan bilgilere bakıldığında ortaokul öğrencilerinin bilişim teknolojilerinden yararlanma düzeyi bilgi edinme boyutu ile toplumsal değerlere yönelik algıları arasında anlamlı bir ilişkinin olmadığ görülmektedir $[\mathrm{r}(408)=.077, \mathrm{p}>.005]$. Yine tablo 5'e bakıldığında araştırma inceleme [r(408)=-.003, p>.005], iletişim $[\mathrm{r}(408)=.026, \mathrm{p}>.005]$, oyuneğlence $[\mathrm{r}(408)=.060, \mathrm{p}>.005]$ ve kendini ifade etme $[\mathrm{r}(408)=.000, \mathrm{p}>.001]$ boyutlarında da anlamlı bir ilişkiye rastlanmamaktadır. Araştırmada elde edilen nicel verileri nitel verilerle açıklamak amacıyla açımlayıcı sıralı desen tercih edilmiştir. Bu bağlamda öğrencilerin bilişim teknolojilerinden yararlanma düzeyleri ile toplumsal değerlere yönelik algıları arasında ilişki olmaması durumunu açıklamak için nitel veriler analiz edilmiştir.

\subsection{Ortaokul Öğrencilerinin Bilişim Teknolojilerinden Yararlanma Ve Toplumsal Değerlere Yönelik Algıları Arasındaki İlişkiye Yönelik Görüşleri Nelerdir?}

Araştırmanın nitel bulguları yarı yapılandırılmış görüşme formunda yer alan sorular dikkate alınarak sunulmuştur. Nitel bulgulara ilişkin oluşan temalar şekil 2'de yer almaktadır.

Sekil 2. Nitel verilere ilișkin temalar

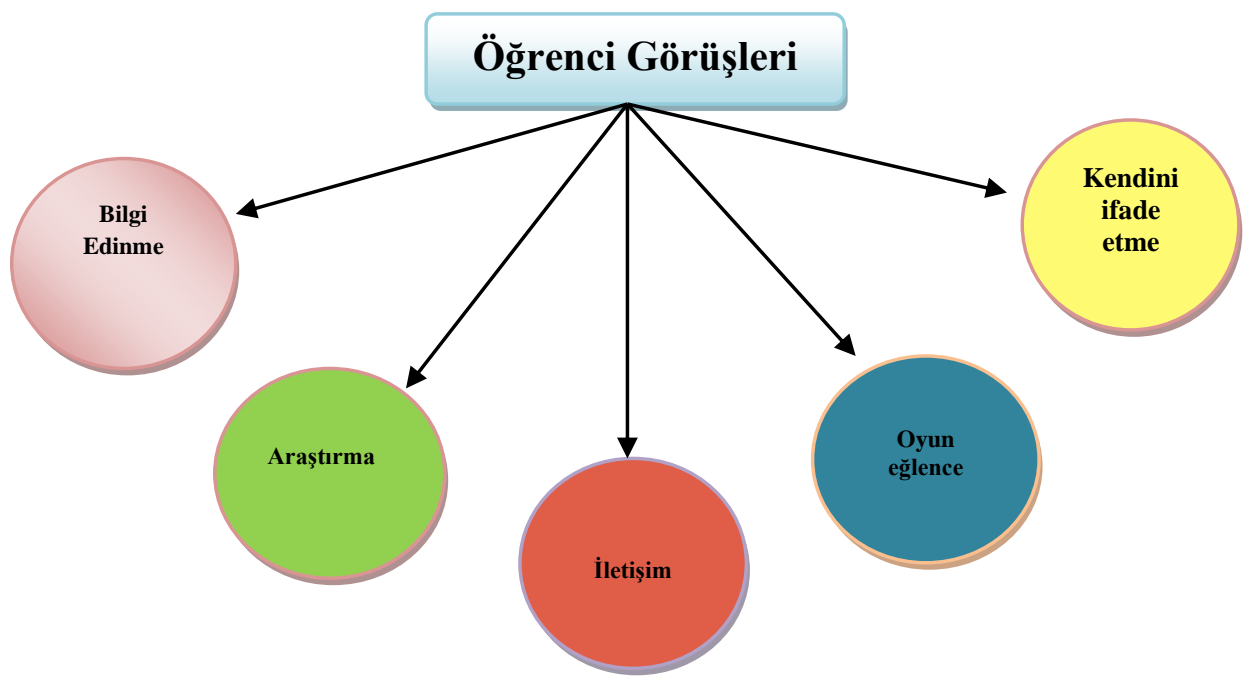


Şekil 2'de nitel verilere iliş̧in olarak beş temanın elde edildiği görülmektedir. Bu temalar Bilişim Teknolojilerinden Yararlanma Ölçeği’nin alt boyutlarına göre oluşturulmuştur. Bilgi edinme teması; öğrencilerin bir konu kakkında bilgi edinmek amacıyla bilişim teknolojilerinden (bilgisayar, telefon, tablet vb.) yararlandıklarında toplumsal değerleri dikkat edip etmeme durumlarını ifade etmektedir. Bu temaya ilişkin öğrenci görüşleri grafik 1'de özetlenmiştir.

Grafik 1. Öğrencilerin bilgi edinme temasına ilişkin görüşleri

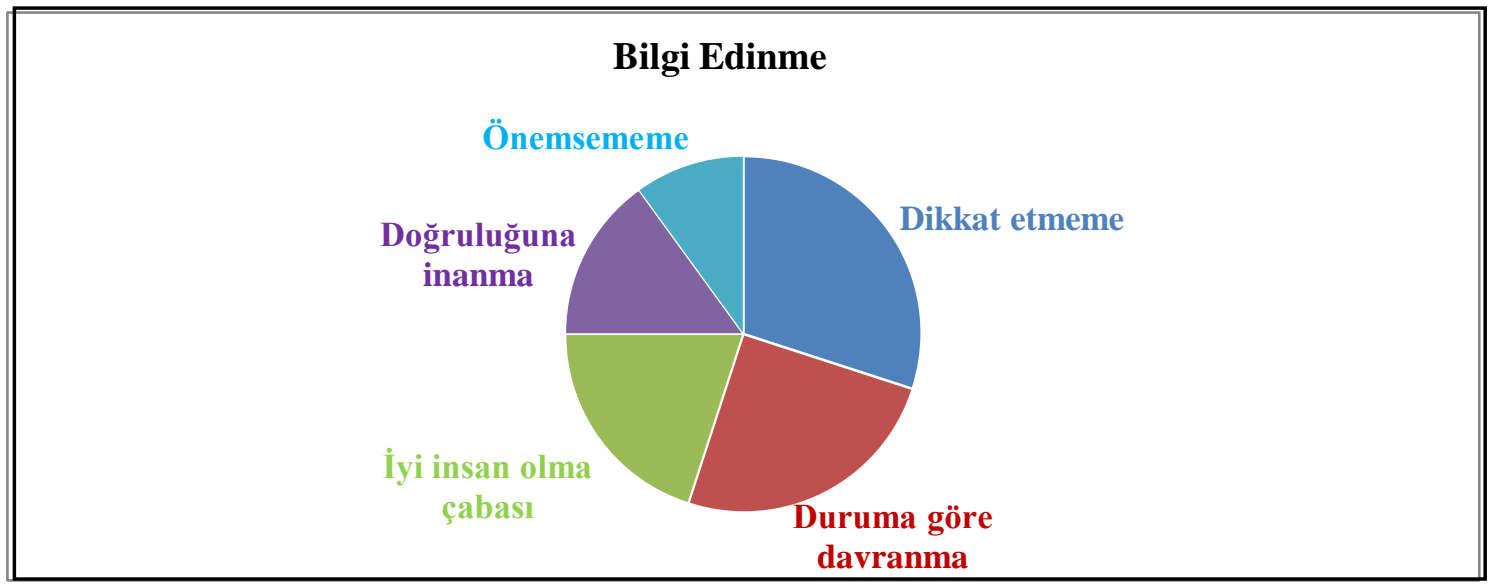

Grafik 1'de görüldüğü gibi bilişim teknolojilerinden bilgi edinmek amacıyla yararlanılırken toplumsal değerleri önemsememe, dikkat etmeme, duruma göre davranma, iyi insan olma çabası ve doğruluğuna inanma görüşlerine vurgu yapılmıştır. Dikkat etmeme bağlamında öğrencilerin bilişim teknolojilerinden yararlanırken toplumsal değerlere uyup uymama konusunda dikkatli davranmadıkları dile getirilmiştir. Duruma göre davranma bağlamında yarar görülen durumlarda toplumsal değerlere uyulduğu, yarar görülmeme durumunda ise uyulmadığ 1 vurgulanmıştır. İyi insan olma çabası bağlamında bilişim teknolojilerinden yararlanırken iyi bir insan olmaya gayret edildiği için toplumsal değerlere uyulduğundan söz edilmiştir. Doğruluğuna inanma bağlamında her koşulda doğru davranılması gerektiğine inanıldığı için toplumsal değerlere uyulduğu dile getirilmiştir. Önemsememe bağlamında ise toplumsal değerlerin çok önemsenmediğinden dolayı bilişim teknolojilerinden bilgi edinmek amacıyla yararlanıldığında bu değerlere uyulmadığı belirtilmiştir. Araştırmaya katılan öğrencilerin bilgi edinme temasına ilişkin bazı görüşlerine aşağıda yer verilmiştir:

Bazen bir şey hakkında bilgiye ihtiyacım olduğunda tabletimden internete girerim. Ama bunu yaparken doğruluk, dürüstlük gibi değerlere dikkat etmem çünkü bu esnada değerler aklıma gelmez. O yüzden dikkat etmem yani. (Aziz)

Öğrenmem gereken bilgilere ulaşırken bazı değerlere dikkat ederim bazılarına etmem. Benim işime geliyorsa ve o bilgi bana lazımsa dürüst olmayı çok düşünmem açıkçası. Geçen bir şey ögrenmek için bir siteye girdim ama site oraya üye olmamı istiyordu. Yaş̧ı tutmadı̆̆ için annemin bilgileri ile üye oldum mesela. Ama haksı duruma düsseceksem zor durumda kalacaksam uyarım tabi. (Elif)

Ben normal hayatımda da dürüst olmaya çalış̧an biriyim. Benim için bilgisayarımı ya da başka bir şeyi ne için kullandiğım fark etmez ben değerlere uyarım. İyi bir insan olmaya çalışan herkes böyle yapar bence. (Zeynep)

Ortaokul öğrencilerinin bilgi edinme amaciyla bilişim teknolojilerinden yararlanıldığında toplumsal değerleri nasıl algıladıklarına ilişkin görüşleri incelendiğinde en çok bu değerlere dikkat etmeme cevabının verildiği görülmektedir. Ayrıca kendilerine fayda sağlama durumuna göre bazı değerlere uyulduğu bazılarına uyulmadığı cevabı dikkat çekmektedir. Bunun yanında bazı öğrencilerin iyi bir insan olabilme çabası ile değerlere dikkat ettikleri de görülmektedir. Bu cevaplar incelendiğinde öğrencilerin bilişim teknolojilerini bilgi 
edinmek amacıyla kullanırken genellikle toplumsal değerleri göz önünde bulundurmadıkları sonucuna ulaşılabilir.

Araştırma-inceleme teması; öğrencilerin araştırma inceleme yapmak amacıyla bilişim teknolojilerinden faydalanırken toplumsal değerlere dikkat edip etmeme durumlarını ifade etmektedir. Bu temaya ilişskin görüşler grafik 2'de yer almaktadır.

Grafik 2. Öğrencilerin araştırma-inceleme temasına ilişkin görüşleri

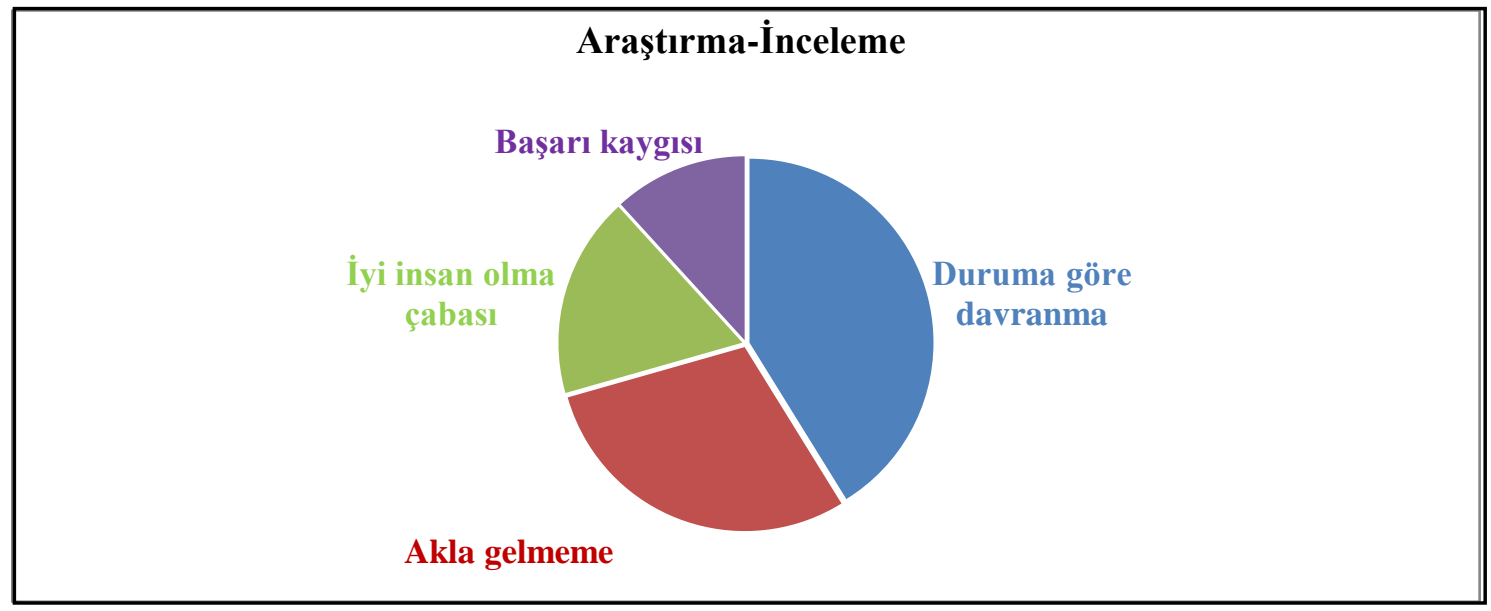

Grafik 2 incelendiğinde bilişim teknolojilerinden araştırma-inceleme amacıyla yararlanılırken toplumsal değerlere uyma konusunda duruma göre davranma, akla gelmeme, iyi insan olma çabası ve başarı kaygısı cevaplarının verildiği görülmektedir. Duruma göre davranma başlığ 1 altında öğrencilerin araştırma inceleme yaparken duruma göre toplumsal değerlere uydukları ya da uymadıkları dile getirilmiştir. Akla gelmeme başlığında ise araştırmainceleme sırasında bu değerlerin akıllarına hiç gelmediğinin üstünde durulurken iyi insan olma çabası başlığında bir önceki temada olduğu gibi öğrencilerin iyi bir insan olma çabası ile değerleri her koşulda dikkate aldıkları vurgulanmıştır. Başarı kaygısı başlığında ise öğrencilerin araştırma inceleme yaparken başarılı olma kaygısı nedeniyle toplumsal değerlere uyduklarından söz edilmiştir. Araştırmaya katılan öğrencilerin araştırma-inceleme temasına ilişkin bazı görüşlerine aşağıda yer verilmiştir:

Öğretmenlerimiz ödev verdiğinde evdeki bilgisayarımdan araş̧tırma yaparım. O ögretmenimiz ödevi yazarak kendisine vermemizi istiyorsa değerlere dikkat ediyorum. Bazı ögretmenlerimiz de ödevleri detayll incelemezler ya da yazılı dosya istemezler bizden. O zaman pek dikkat etmem. Bazı sitelerden ödevi bulur yazarım. (Hasan)

Ben bir ödevim hakkında araşttrma yaparken herhangi bir değer aklıma gelmez. Araştırmamı yaparım ve ödevimi hazırlarım. Aklıma gelmeyen bir şey için de acaba uydum mu uymadım mı diye düşünmem açılkçasl. (Mehmet)

Bizim ögretmenlerimiz ödevlere çok önem verir. Ben araştırma yapacaksam bu değerlere uymaya çallşırım. Yanlış bir şey yaparsam zaten öğretmenim anlar ve bana kötü not verir. Bu da beni kötü hissettirir. (Arzu)

Öğrencilerin araştırma-inceleme temasına ilişkin görüşleri incelendiğinde genellikle duruma göre davrandıkları ya da toplumsal değerlerin akıllarına gelmediğine ilişkin cevapları göze çarpmaktadır. Ayrıca başarılı olma kaygısı ya da başarısızlık korkusu ile bazı öğrencilerin toplumsal değerlere uymaya çalıştıkları da bu temada ilk defa vurgulanmıştır. Bu cevaplar incelendiğinde öğrencilerin bilişim teknolojilerini araştırma inceleme yapmak amaciyla kullanırken toplumsal değerlerle bağ kuramadıkları sonucuna ulaşılabilir. Zira bu değerlerle bağ kurulabilen zamanlarda dahi duruma göre yani öğretmenin tutumuna göre davranılması da değerlerin öneminin yeterince anlaşılmadığını göstermektedir. 
İletişim teması; öğrencilerin bilişim teknolojilerini iletişim kurmak amacıyla kullandıklarında toplumsal değerlere ne kadar dikkat ettiklerini belirten durumları ifade etmektedir. Öğrencilerin iletişim temasına ilişkin görüşleri grafik 3’te özetlenmiştir.

Grafik 3. Öğrencilerin iletişim temasına ilişkin görüşleri

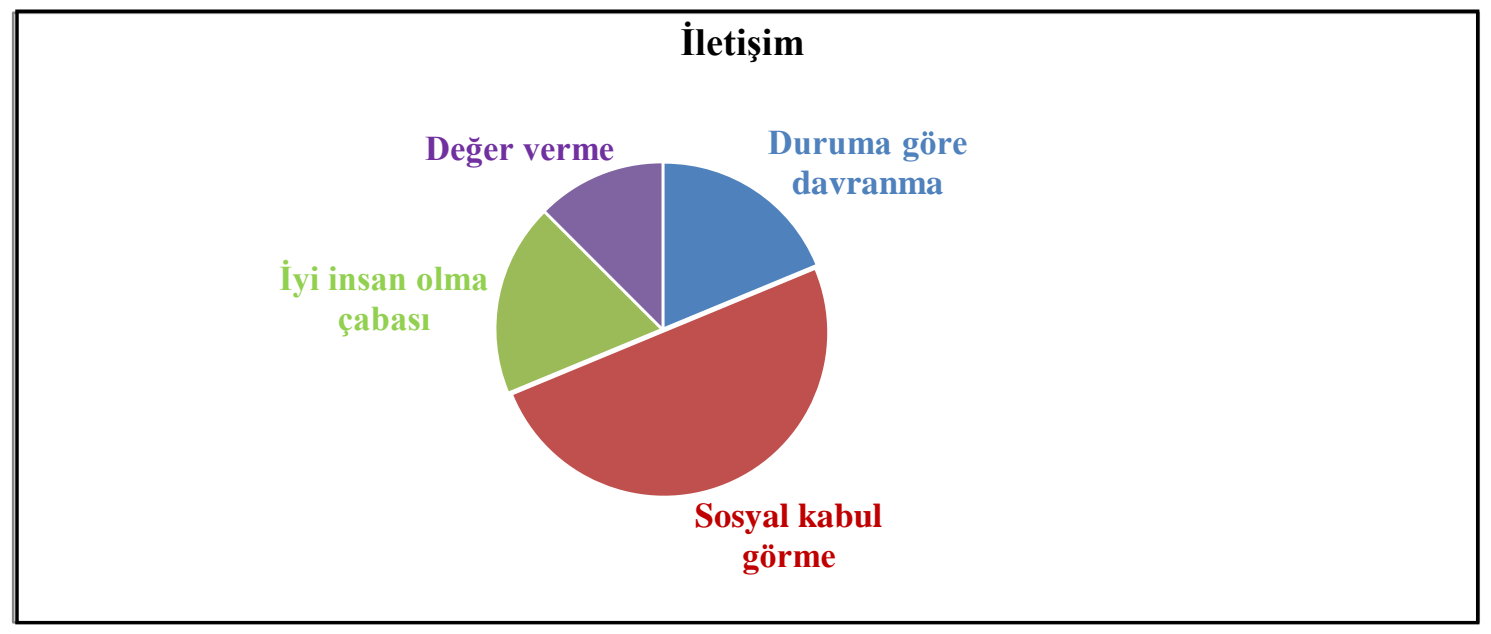

Grafik 3'e bakıldığında bilişim teknolojilerinden iletişim amacıyla yararlanırken sosyal kabul görme, duruma göre davranma, iyi insan olma çabası ve değer verme görüşlerinden söz edildiği görülmektedir. Sosyal kabul görme görüşüne ilişkin olarak öğrencilerin bilişim teknolojilerini iletişim amacıyla kullanırken ayıplanma, dışlanma, hoş görülmeme gibi kaygılardan dolayı toplumsal değerlere uydukları dile getirilmiştir. Duruma göre davranmaya ilişkin olarak ise iletişim kurulan kişinin kendilerini tanıyıp tanımamalarına veya sanal ortamda açı kimliklerini kullanıp kullanmama durumuna göre toplumsal değerlere uydukları ya da uymadıklarından söz edilmiştir. İyi insan olma çabasına ilişkin olarak bilişim teknolojilerinden iletişim amaçlı yararlanırken iyi bir insan olmaya gayret edildiği görüşü bu temada da yinelenmiştir. Araştırmaya katılan öğrencilerin iletişim temasına ilişkin çeşitli görüşlerine aşağıda yer verilmiştir:

Biri ile yazışlyorken ya da whatsapp grubumuzda bir şey paylaşlyorken dikkat ediyorum. Sonuçta konuş̧ı̆̆um kişi görüş̧üğüm kişiler. Yanlış bir şey yazdığımda kimse beni sevmeyebilir ya da insanlar benim hakkımda kötü düşünebilir. Bana doğru gelen şeyleri elbette söylerim ama kimseyi üzmem. (Sevim)

Internette tanımadiğım insanlarla bir şey paylaşıyorsam çok önemsemem yazdlklarımın doğru olmasını. Sonuçta beni tanımıyor. Ben de onu tanımıyorsam neden her şeyimi paylaşayım. Hem bu bana zarar da verebilir. Ama konuştuğum kişi tanıdığımsa kendim gibi yazarım tabi. (Musa)

Biri ile iletişsim kuruyorsam bu ona değer verdiğim içindir. Zaten benim için değerli olmayan kişilerle hiç konuşmam ben. Bu yüzden değerlere de dikkat ederim. (Hatice)

Dürüst olmak benim için önemlidir. Ben iyi olmazsam karşımdaki de bana karşı iyi olmaz. Ben yalan söylersem o da söyler. Ya da o yalan söylese bile ben söyleyemem. Başkası kötü olabilir ama ben olamam. (Ahmet)

Öğrencilerin iletişim teması ile ilgili görüşleri incelendiğinde çoğunlukla sosyal kabul görme kaygısıyla toplumsal değerlere uyulmaya çalışıldığı anlaşılmaktadır. Bununla birlikte bu temada duruma göre davranılan cevaplarda bunun sebebini açık kimlikleri ile iletişim kurup kurmama durumu ile bağdaştırmaları da göze çarpmaktadır. Yine bu temada iletişim kurulan kişinin değerli olduğundan dolayı toplumsal değerlere uyulduğu da vurgulanmıştır. Bu cevaplar göz önüne alındığında diğer temalardan farklı bir durumun ortaya çıktığı ve toplumsal değerlere uyma konusundaki cevapların daha ağırlıkta olduğu söylenebilir. Bu durumun öğrencilerin iletişim kurarken karşılarında bir muhataplarının bulunmasından kaynaklandığı ileri sürülebilir. 
Oyun-eğlence teması; öğrencilerin bilişim teknolojilerinden yararlanırken toplumsal değerlere dikkat edip etmeme durumlarını ifade etmektedir. Öğrencilerin bu temaya ilişkin görüşleri grafik 4'te özetlenmiştir.

Grafik 4. Öğrencilerin oyun-eğlence temasına ilişkin görüşleri

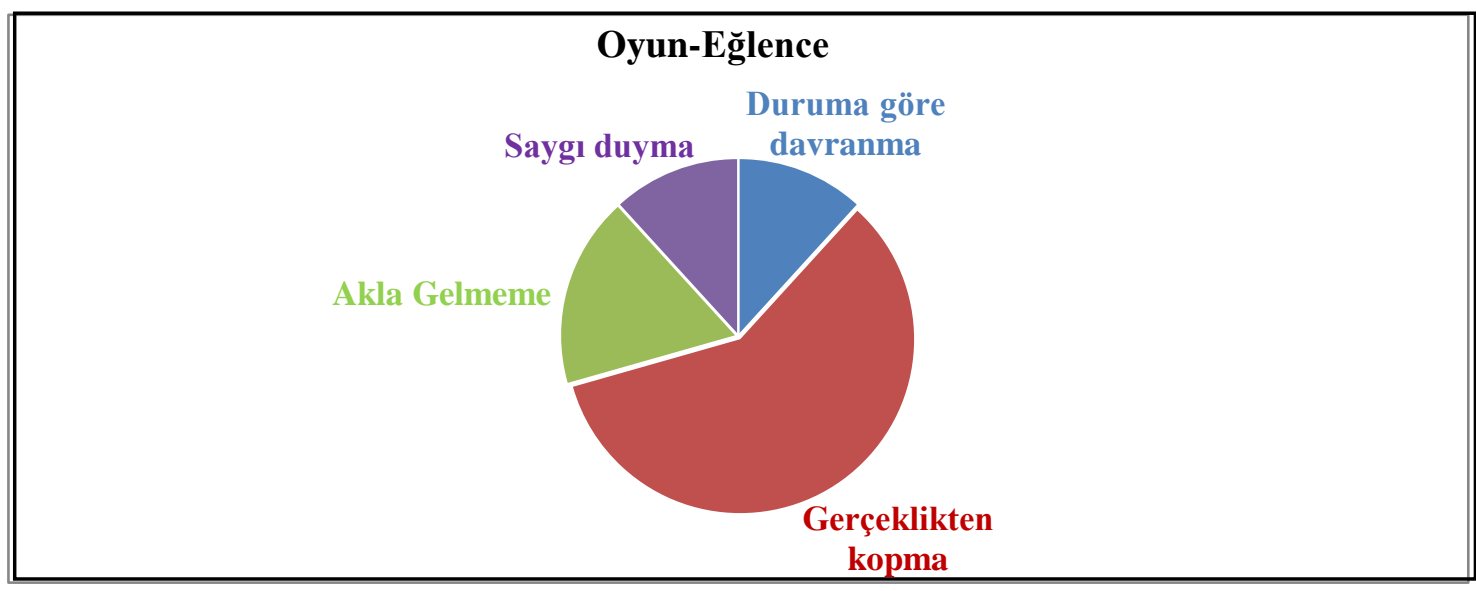

Grafik 4'te görüldüğü üzere bilişim teknolojilerinden oyun-eğlence amaciyla yararlanılırken toplumsal değerlere ilişkin gerçeklikten kopma, duruma göre davranma, akla gelmeme ve sayg1 duyma görüşlerinden söz edilmiştir. Gerçeklikten kopma bağlamında öğrenciler, oyun ve eğlencenin gerçek hayattan farklı bir ortamda rahatlamak amaciyla faydalanıldığını düşündükleri için toplumsal değerlere uyulmadığını dile getirmiştir. Akla gelmeme başlığında bilişim teknolojilerinden oyun-eğlence amaçlı yararlanılırken toplumsal değerleri düşünmediklerinden bahsedilmiştir. Duruma göre davranmaya ilişkin olarak ise gerçek kişilerle eş zamanlı çok kişili oyunların oynanması ya da bilgisayara karşı oynama durumuna göre toplumsal değerlere uyulduğu ya da uyulmadığı vurgulanmıştır. Saygı başlığına ilişkin olarak ise oyunlarda rakibe saygı duyulduğu için toplumsal değerlere uyulduğu ifade edilmiştir. Araştırmaya katılan öğrencilerin oyun-eğlence temasına ilişkin bazı görüşlerine aşağıda yer verilmiş̧tir:

Bilgisayar oyunları oynarken değerlere uymaya çok dikkat etmem. Sonuçta oyun bu yani gerçek değil. Rahatlamak için oynuyorken ve kimseye zarar verme durumu yokken gerçek olmayan bir dünya için ne diye dikkat edeyim. (Burak)

Arkadaşlarımla bilgisayarda aynı anda oyun oynadığımda ya da karşımda gerçek kişiler olduğunda değerleri dikkate alırım. Hile yapamam, oyun içerisinde onlara yazarken düzgün konuşurum. Ama bazen bilgisayara karşı oynuyorum. Yenilince canım siklliyor internetten oyunun hilelerini buluyorum ölümsüzlük falan yapıyorum o zaman dikkat etmem buna. (Yusuf)

Genelde moda tasarımı gibi oyunlar oynarım tabletimden. Bunları oynadı̆̆ımda değerler aklıma gelmez. Bu yüzden hiç düşünmedim acaba değerlere dikkat ediyor muyum etmiyor muyum diye. (Ayşe)

Öğrencilerin oyun-eğlence teması ile ilgili görüşleri irdelendiğinde en çok oyunların sanal bir dünyada oynanmasından dolayı toplumsal değerlere uymadıkları dikkat çekmektedir. $\mathrm{Bu}$ temada bilişim teknolojilerini kullanırken toplumsal değerlerin akla gelmediği ya da duruma göre davranıldığı görüşleri de yinelenmiştir. Bu cevaplar göz önüne alındığında öğrencilerin sanal dünyayı değerlere uyulacak bir yer olarak görmedikleri şeklinde nitelendirilebilir.

Kendini ifade etme teması; öğrencilerin bilişim teknolojilerini kendini ifade etmek amacıyla (kendi hakkında sosyal medyada paylaşımda bulunma, blog yazma, twit atma vb.) kullanırken toplumsal değerleri dikkate alma durumlarını ifade etmektedir. Öğrencilerin kendini ifade etme temasına ilişkin görüşleri grafik 5'te özetlenmiştir. 
Grafik 5. Öğrencilerin kendini ifade etme temasına ilişkin görüşleri

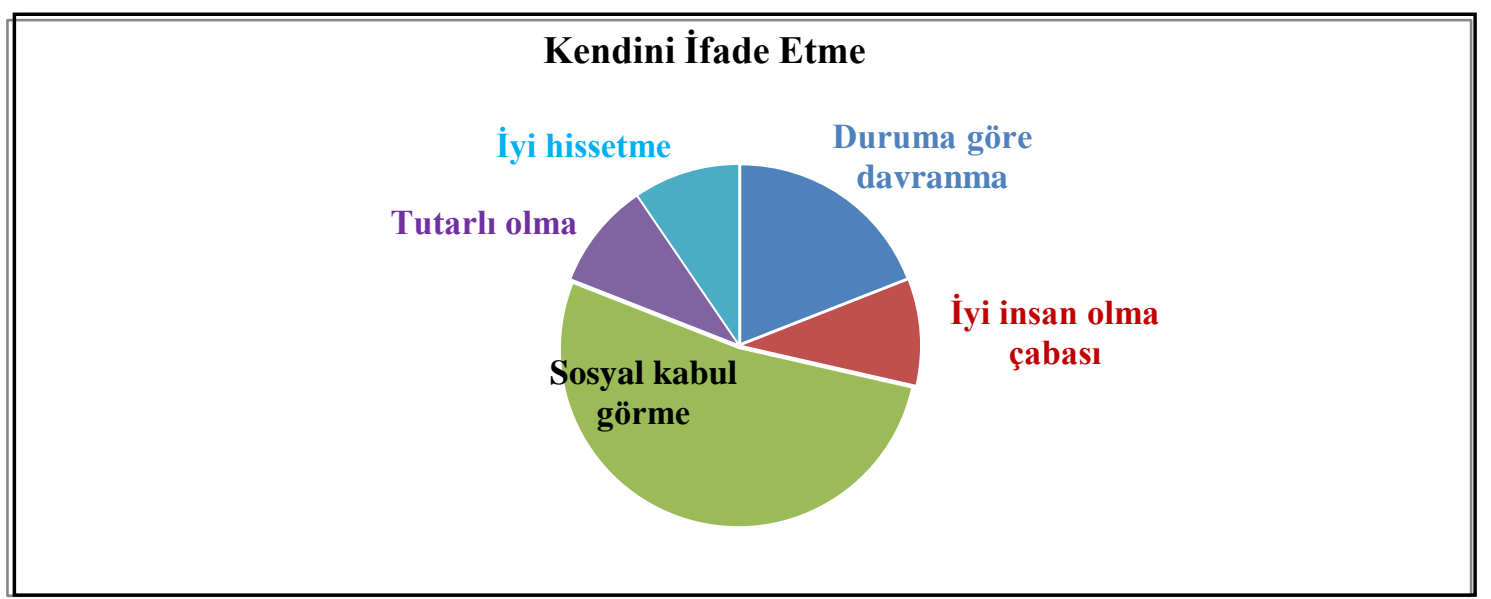

Grafik 5’te görüldüğü gibi bilişim teknolojilerinden kendini ifade etme amaciyla yararlanılırken toplumsal değerlere ilişkin olarak sosyal kabul görme, iyi insan olma çabası, duruma göre davranma, iyi hissetme ve tutarlı olma görüşleri dile getirilmiştir. Sosyal kabul görme anlamında öğrencilerin bilişim teknolojileri ile kendilerini ifade ederlerken beğenilmeme, yalnızlaşma ve saygı duyulma kaygılarından dolayı toplumsal değerlere uyduklarından söz edilmektedir. Duruma göre davranma bağlamında öğrencilerin gerçek isimlerini kullandıkları ya da takma isimle tanınmadan kendilerini ifade ettikleri durumlara göre toplumsal değerlere uydukları ya da uymadıkları vurgulanmıştır. İyi hissetme başlığında ise öğrencilerin kendilerini iyi hissettirmesi nedeniyle toplumsal değerlere uydukları ifade edilmektedir. Tutarlı olma anlamında ise gerçek hayatta oldukları kişiden farklı davranmamak adına kendilerini ifade ederken toplumsal kurallara uydukları dile getirilmiştir. Araştırmaya katılan öğrencilerin kendini ifade etme temasına ilişkin çeşitli görüşleri aşağıda yer almaktadır:

Kendimle ilgili bir şey yazarken toplumsal değerlere dikkat etmeye çallşırım. Çünkü beni tanıyan insanlar sayfama girip bunları okuyorlardır. Saçma bir şey yazıp da başkalarının bana gülmesine katlanamam. Arkadaşlarımı kaybederim ailem de üzülür buna. (Süreyya)

Kendimi ifade ettiğimde bazen abarttı̆̆ım olurdu. Kendimi kötü hissetmiş̧tim o zaman. Ondan sonra hep doğru şeyler yazdım ve kendimi iyi hissettim. Bu yüzden değerli davranmaya çalışlyorum artık (Zümrüt)

Normal hayatımda nasllsam kendimi ifade ederken de öyleyim. Bu yüzden kendimle ilgili bir şey yazlyorsam değerlere de dikkat ediyorumdur. Başka türlü davranırsam yazdı̆̆ım şeyler aslinda benden çok farklı birinin düşünceleri olur. Başkalarını kandırsam da kendimi kandıramam (Defne)

Bazen söylemek istediğim ama çekindiğim şeyleri internette takma ismimle paylaşttğımda tüm bilgilerimi veremem. Adımı, yaşımı falan saklarım doğruyu söylersem tanırlar çünkü. Ama kendi gerçek ismimle bir şey yazıyorsam çok dikkat ederim. (Musa)

Öğrencilerin kendini ifade etme temasına ilişkin görüşlerine bakıldığında iletişim temasında olduğu gibi sosyal kabul görme kaygısının toplumsal değerlere uyma konusunda onları motive ettiği söylenebilir. Öğrencilerin kendilerini ifade ederken tutarlı olmaya çalışmaları ve böyle davranmanın kendilerini iyi hissettirdiği de bu temada vurgulanan yeni bir görüş olarak dikkat çekmektedir. $\mathrm{Bu}$ bağlamda öğrencilerin kendilerini ifade ederken çoğunlukla kendi kimliklerini kullandıkları ve toplumda kabul görme adına toplumsal değerlere uymaya çalıştıkları yorumuna ulaşmak mümkündür.

Tablo 7'ye göre bilişim teknolojilerinden yararlanma ölçeğinin bilgi edinme boyutu ile toplumsal değerlere yönelik algı arasında zayıf bir ilişki olduğu belirlenmiştir. Nitel veriler incelendiğinde bu durumun öğrencilerin araştırma inceleme yaparken toplumsal değerlerin 
dikkat etmediklerini ya da duruma göre davrandıklarını belirten ifadeleri ile açıklanabilir. Başka bir deyiş̧le nitel verilerin nicel verileri desteklediği söylenebilir.

Araştırma-inceleme boyutunda ise toplumsal değerlerle negatif yönde zayıf bir ilişki olduğu görülmektedir. Nitel bulgulara bakıldığında bu durum öğrencilerin araştırma inceleme yaparken toplumsal değerlerin akıllarına gelmediği ya da duruma göre davrandıkları yönündeki görüşleri ile açıklanabilir. Bu boyutta da yine nitel verilerin nicel verileri desteklediği ileri sürülebilir. Araştırmanın nitel bulguları sonucu oluşan tüm temalar ve alt temalar ile bunlara ilişkin frekanslar şekil 3 'te yer almaktadır.

Șekil 3. Nitel verilere ilișkin tema, alt tema ve frekanslar

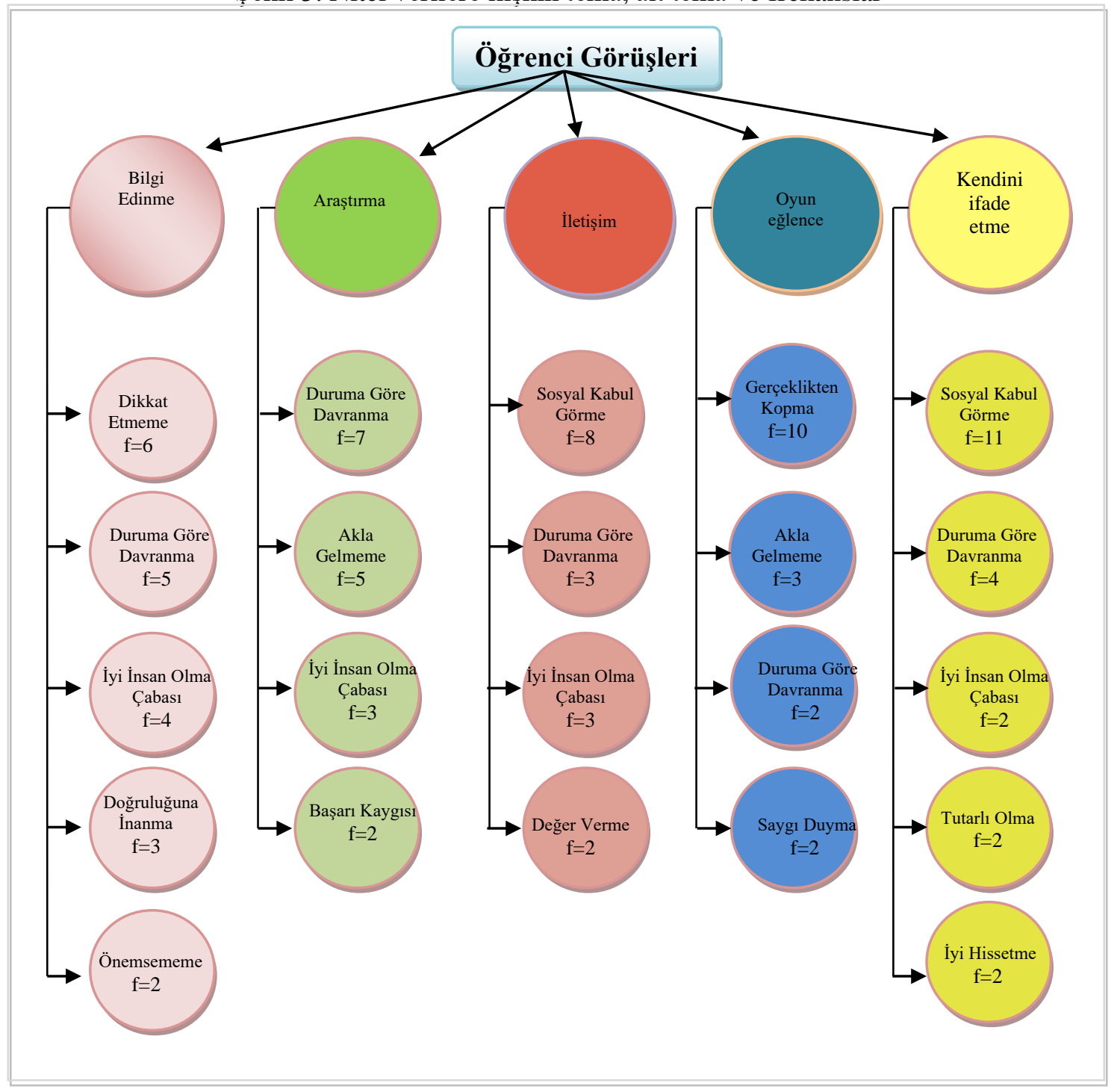

Sonuç ve Öneriler

Öğrencilerin teknolojik araçları akıllı ve üretken yöntemlerle kullanmaları için onlara yardımcı olarak bu araçları daha geniş bir topluluk oluşturmada, sorumlu davranmada hem ulusal hem de küresel olarak sağliklı ve üretken bir geleceği hayal etmelerini sağlamamız gerekmektedir (Ohler, 2011). Bu noktada öğrencilerin bilişim teknolojilerini kullanma düzeylerine vurgu yapılırken bir yandan da değerlere uygun davranış göstermenin önemi ortaya çıkmaktadır. Mevcut araştırmada ortaokul öğrencilerinin bilişim teknolojilerinden yararlanma düzeyleri ve toplumsal değerlere yönelik algıları arasındaki ilişki araştırılmıştır. 
Araştırma sonuçlarına göre öğrencilerin bilişim teknolojilerinden yararlanma düzeylerinin genel olarak orta düzeyde olduğu sonucuna ulaşılmıştır. Bununla birlikte bilgi edinme, araştırma inceleme, oyun eğlence ve iletişim alt boyutlarında orta düzeyde; kendini ifade etme alt düzeyinde ise düşük düzeyde olduğu görülmüştür. Özmusul (2012) tarafından ilköğretim ikinci kademe öğrencilerinin bilişim teknolojilerinden yararlanma düzeylerinin belirlenmesi amacıyla yapılan çalışmada da aynı sonuçlara ulaşılmış ve kendini ifade etme alt boyutu dişındaki tüm alt boyutlarda öğrencilerin bilişim teknolojilerinden yararlanma düzeylerinin orta düzeyde olduğu bulunmuştur. Benzer sonuçlara Çetin, Yalçınkaya, Aktepe ve Temur (2018)'un güncel bir çalışmasında da rastlanmış ve ortaokul öğrencilerinin bilişim teknolojilerinden yararlanma düzeylerinin orta düzeyde (genellikle seviyesinde) olduğu görülmüştür. Demirer ve Yolcu (2018) tarafından öğrencilerin bilişim teknolojilerinden yararlanma düzeylerini saptamaya yönelik olarak yapılan bir çalışmada ise öğrencilerin bilişim teknolojilerinden yararlanma düzeylerinin ortalama değerlerin üzerinde olduğu saptanmıştır. Mevcut çalışmada öğrencilerin teknolojiyi kullanma düzeylerinin orta düzeyde çıkması teknolojiye ulaşma imkânlarının artması ile açıklanabilir. Grunwald (2004) 13 ila 17 yaş arasındaki çocukların günde ortalama üç buçuk saati dijital medyada geçirdiklerini ileri sürmesi yeni neslin teknolojiye erişimde geldiği noktayı özetlemektedir. Zira nitel bulgularda öğrencilerin bilgisayar, tablet ve telefon gibi teknolojik araçlardan sik sik yararlandıklarını belirten ifadeleri de bunu doğrular niteliktedir.

Araştırmanın başka bir sonucunda öğrencilerin toplumsal değerlere yönelik algılarının daha çok olumlu yönde olduğu ortaya çıkmıştır. Botha, Joubert ve Hugo'nun (2016) öğrencilerin demokratik değerlere yönelik algılarını belirlemeye yönelik çalışmalarında öğrencilerin demokratik değerlere karşı saygı ve sorumluluk duydukları, başka bir değişle değerlere karşı olumlu algılara sahip oldukları belirlenmiştir. Altunay ve Yalçınkaya (2011) tarafından öğretmen adayı öğrencilerin değerlere ilişkin görüşlerinin incelendiği çalışmada öğretmen adaylarının geleneksel, evrensel ve hedonistik değer alanlarına yüksek düzeyde önem verdikleri belirlenmiştir. Kale ve Demir (2015) tarafından toplumsal değer algılarının karşılaştırılması amacıyla yapılan bir çalışmada ise bağımsız sınıflarda okuyan öğrencilerin toplumsal değerlere ilişkin olumlu algılarının ortalaması olumsuz algılarının ortalamasından yüksek bulunmuştur. Ergün Kaplan ve Sulak (2017) tarafından yapılan bir çalışmada ise ortaokul öğrencilerinin toplumsal değerlere olan bakış açısı irdelenmiş ve sonuçlarda da öğrencilerin aile ile ilgili olan değerlere bakış açılarının olumlu olduğu raporlanmıştır. Yine aynı çalışmanın sonuçlarında öğrencilerin dürüstlüğü önemsedikleri ve sorumluluk ile ilgili değerleri gerekli gördükleri vurgulanmıştır. Bu araştırmada da öğrencilerin toplumsal değerlere yönelik algılarının olumlu yönde olması bu değerleri önemsedikleri ve bu sayede iyi bir insan olabileceklerine inanmaları ile açıklanabilir. Nitel bulgularda kimi öğrencilerin sosyal kabul görmeyi önemsedikleri ve iyi bir insan olmak adına toplumsal değerlere uymaya çalıştıklarını belirten ifadeleri de bu sonucu destekler niteliktedir.

Araştırmanın en çarpıcı sonucu olarak öğrencilerin bilişim teknolojilerinden yararlanma düzeyleri ile toplumsal değerlere yönelik algıları arasında pozitif yönde güçlü ve anlamlı bir ilişki olmadığı ortaya çıkmıştır. Mevcut çalışmayı alanyazındaki diğer çalışmalardan ayıran bu sonuç, araştırmadan elde edilen nitel bulgular 1şı̆̆ında değerlendirildiğinde öğrencilerin bilişim teknolojilerinden bilgi edinme, araştırma-inceleme yapma ve oyun eğlence amaçlı yararlanırken toplumsal değerleri çok fazla dikkate almadıklarını göstermektedir. Ayrıca bu sonuç iki değişken arasında neden anlamlı bir ilişkinin olmadığını ortaya koymak adına da önemlidir. Nitekim nitel bulgulara bakıldığında bu boyutlarda oluşan temalarda da öğrencilerin bilişim teknolojilerinden yararlanırken toplumsal değerlere yönelik olarak "akla gelmeme" ve "dikkat etmeme" cevaplarını sık kullandıklarının görülmesi bu sonucu açıklamaktadır. Ancak öğrencilerin bilişim teknolojilerinden iletişim ve kendini ifade etme amaçlı yararlanırken sosyal kabul görme ve iyi bir insan olma çabası ile bu değerlere dikkat ettikleri sonucu da oldukça dikkat çekicidir. Oblinger ve Oblinger (2005) internetin insanların kişiliğini değiştirmediğini fakat içe dönük kişilere yeni insanlara ulaşma fırsatı verirken dışa dönüklere de arkadaş 
çevrelerini genişletme fursatı sunduğunu vurgulamaktadır. Nitel bulgularda öğrencilerin bilişim teknolojilerinden iletişim ve kendilerini ifade etme amaçlı yararlanırken arkadaş çevrelerini genişletme ve sosyal kabul görme kaygısı ile değerlere dikkat ettiklerini belirtmeleri de bu sonucu açıklamaktadır. Bu bulgulardan, öğrencilerin bilişim teknolojilerinden yararlanırken karşılarında kendilerini tanıyan birilerinin bulunduğu yani sosyal kabul görme durumunu etkileyecek durumlarda toplumsal değerlere dikkat ettikleri, daha sanal ortamlarda ve açık kimliklerini gizlediklerinde ise toplumsal değerlere uymaya dikkat etmedikleri sonucuna ulaşılabilir. Zira nitel bulgulara ilişkin tüm temalarda öğrencilerin bilişim teknolojilerinden yararlanırken toplumsal değerleri algılama konusunda "duruma göre davranma" görüşlerinin öne çıkması bu sonucun nedeni olarak gösterilebilir. Çalışmada ulaşılan sonuçlar 1şığında aşağıdaki öneriler geliştirilmiştir;

Öğrencilerin bilişim teknolojilerinden yararlanırken genellikle duruma göre davrandıkları ve internet ortamında tanınmadıklarını düşündükleri durumlarda toplumsal değerlere çok dikkat etmedikleri belirlenmiştir. Öğrencilerin gerçek hayatta olduğu kadar insanın var olduğu her türlü ortamda toplumsal değerlerin önemli olduğunu fark etmelerini sağlamak gerekmektedir. Bu farkındalığı sağlamak adına öğretmenlerin özellikle bilişim teknolojilerinin kullanıldığı etkinliklerde örnek uygulamalara yer vererek toplumsal değerlere dikkat çekmeleri önerilmektedir. Ayrıca öğrencilerin bilişim teknolojilerini doğru ve uygun kullanmalarını sağlamak amacıyla öğretmenlere ve öğrencilere dijital vatandaşlık eğitimi verilebilir. Bunun için öğretmenlere dijital vatandaşlık kavramına yönelik hizmet-içi eğitim faaliyetleri düzenlenmesi önerilmektedir. Bunun yanında MEB Eğitim Bilişim Ağında (EBA) yer alan dijital vatandaşlığa ilişkin videolardan da faydalanılabilir.

$\mathrm{Bu}$ çalışmada öğrencilerin bilişim teknolojilerinden yararlanma düzeyleri ile toplumsal değerlere yönelik algıları arasındaki ilişki araştırılmıştır. İlerde yapılacak çalışmalarda ögrencilerin bilişim teknolojilerinden yararlanma düzeyleri ile başka değer türleri arasındaki ilişki incelenebilir. Bu araştırmanın çalışma grubu 2017/2018 eğitim/öğretim yılında Mersin ili merkez ilçelerinde öğrenim gören ortaokul öğrencileri ile sınırlı tutulmuştur. Benzer bir araştırma örneklemi genişletilerek daha geniş bir kapsamda ele alınabilir. Araştırmanın katılımcı grubu ortaokul ögrencilerinden oluşmaktadır. Benzer bir çalışma lise ya da üniversite öğrencilerinden oluşan bir grupta tekrar edilerek sonuçları bakımından bu çalışma ile karşılaştırılabilir.

\section{Kaynakça}

Altunay, E., \& Yalçınkaya, M. (2011). Öğretmen adaylarının bilgi toplumunda değerlere ilişkin görüşlerinin bazı değişkenler açısından incelenmesi. Kuram ve Uygulamada Ĕgitim Yönetimi Dergisi, 17(1), 5-28.

Arabacı, I. B. (2012). İlköğretim II. kademe öğrencilerinin bilişim teknolojilerinden yararlanma düzeyleri. Education Sciences, 7(1), 184-191.

Aypay, A. (2015). Araştırma yöntemleri desen ve analiz (2.b.). Anı Yayıncıl1k: Ankara.

Bakaç, E. (2013). Toplumsal değerlere yönelik algı ölçeği: geçerlik ve güvenirlik çalışması. Ĕgitim ve Öğretim Araştırmaları Dergisi, 2(4), 303-309.

Botha, A., Joubert, I., \& Hugo, A. (2016). Children's perceptions of democratic values: Implications for democratic citizen education. South African Journal of Childhood Education, 6(1), 1-8.

Cabı, E., Erdem, E., \& Kırkan, B. (2016). Ortaokul öğrencilerinin bilişim teknolojilerinden yararlanma ve üst bilişsel farkındalık düzeylerinin çeşitli değişkenlere göre incelenmesi. Karaelmas Eğitim Bilimleri Dergisi, 4(2), 92-103. 
Chu, H.C. (2014). Potential negative effects of mobile learning on students' learning achievement and cognitive load - a format assessment perspective. Journal of Educational Technology \& Society, 17(1), 332-344.

Creswell, J. W. (2007). Qualitative inquiry \& research design: Choosing among five approaches (2. b.). Thousand Oaks, CA: Sage.

Creswell, J.W., \& PlanoClark, V.L. (2015). Karma yöntem araştırmaları tasarımı ve yürütülmesi (2. b.) (Y. Dede ve S.B. Demir, Çev. Ed.). Ankara: Anı.

Çalık, D., \& Çınar, Ö. P. (2009). Geçmişten günümüze bilgi yaklaşımları bilgi toplumu ve internet. XIV. Türkiye'de Internet Konferanst, 12-13.

Çetin, O., Yalçınkaya, E., Aktepe, V., \& Temur, M. (2018). Ortaokul öğrencilerinin bilişim teknolojilerinden yararlanmaya ilişkin görüşlerinin incelenmesi. International Journal of Active Learning, 3(2), 11-22.

Çubukçu, Z., Eker Özenbaş, D., Çetintaş, N., Satı, D., Yazlık Şeker, Ü. (2012). Yönetici, öğretmen, öğrenci ve veli gözünde öğretmenin sahip olması gereken değerler. Pegem Eğitim ve Öğretim Dergisi, 2(1), 25-38.

Demirer, V., \& Yolcu, V. (2018). Meslek yüksek okulu öğrencilerinin bilişim teknolojilerinden yararlanma düzeyleri ile akademik başarıları arasındaki ilişki. Mehmet Akif Ersoy Üniversitesi Eğitim Fakültesi Dergisi, 45,105-131.

Demircioğlu, İ. H., \& Tokdemir, M. A. (2008). Değerlerin oluşturulma sürecinde tarih eğitimi: Amaç, işlev ve içerik. Değerler eğitimi dergisi, 6(15), 69-88.

Denizci, Ö. M. (2009). Bilişim toplumu bağlamında internet olgusu ve sosyopsikolojik etkileri. Marmara İletişim Dergisi, 15, 47-65.

Ergün Kaplan, S. ve Sulak, S.A. (2017). Ortaokul öğrencilerinin toplumsal değerlere yönelik bakış açılarının farklı değişkenlere göre incelenmesi. Bartın Üniversitesi Eğitim Fakültesi Dergisi, 6(3), 840-858.

Erişen, Y., \& Çeliköz, N. (2007). Eğitimde bilgisayar kullanımı. Ö. Demirel, E. Altun (Ed), Ögretim teknolojileri ve materyal tasarımı. Ankara: PegemA Yayıncılık.

Grunwald, P. (2004). Children, families, and the internet: National survey and report. Prepared by Grunwald Associates, San Mateo, CA. http://www.grunwald.com/pdfs/CHILDRENFAMILIES-AND-INTERNET-2000.pdf (Erişim tarihi: 11.12.2018).

Hopson, M. H., Simms, R. L., \& Knezek, G. A. (2001). Using a technology-enriched environment to improve higher-order thinking skills. Journal of Research on Technology in education, 34(2), 109-119.

Kale, M. \& Demir, S. (2015). Birleştirilmiş ve bağımsız sınıflarda öğrenim gören öğrencilerin toplumsal değer algılarının karşılaştırılması. Bartın Üniversitesi Eğitim Fakültesi Dergisi, 111-118.

Karasar, N. (2017). Bilimsel araştırma yöntemi (32.Bask1). Ankara: Nobel Akademik.

Khirwadkar, A. (2007). Integration of ICT in education: Pedagogical issues. Education, 85-104.

MEB (2018). Sosyal bilgiler dersi öğretim programı (ilkokul ve ortaokul 4,5,6, ve 7. sinıflar). http://mufredat.meb.gov.tr/Dosyalar/201812103847686SOSYAL\%20B\%C4\%B0LG\%C4\% B0LER\%20\%C3\%96\%C4\%9ERET\%C4\%B0M\%20PROGRAMI\%20.pdf (Erişim tarihi: 12.10.2018).

Miles, M. B. \& Hubermann, A. M. (1994). Qualitative data analysis. ThousandOaks, CA: Sage Publication. 
Mukti, N. A., \& Hwa, S. P. (2004). Malaysian perspective: Designing interactive multimedia learning environment for moral values education. Educational Technology \& Society, 7(4), 143-152.

Oblinger, D., \& Oblinger, J. (2005). Is it ageor IT: First steps toward understanding the net generation. Educating the net generation, 2(1-2), 20.

Ohler, J. (2011). Digital citizenship means character education for the digital age. Kappa Delta Pi Record, 47(1), 25-27.

Özmusul, M. (2008). Illköğretim ikinci kademe ögrencilerinin bilgi ve iletişim teknolojilerinden yararlanma düzeylerinin incelenmesi (Kilis İli örneği) (Yayınlanmamış yüksek lisans tezi). Gaziantep Üniversitesi, Gaziantep.

Özmusul, M. (2011). Bilişim teknolojilerinden yararlanma ölçeğinin geliştirilmesi. Kuramsal Eğitimbilim Dergisi, 4(1), 1-17.

Özmusul, M. (2012). An analysis of the aims related to education system in the vizyon 2023 in terms of international indicators. Journal of Turkish Science Education, 9(3), 97-114.

Rokeach, M. (1973). The nature of human values. New York: Free Press.

Schwartz, S. H. (1996). Value priorities and behavior: Applying of theory of integrated value systems. In C. Seligman, J. M. Olson, \& M. P. Zanna (Eds.), The Psychology of Values: The Ontario Symposium, Vol. 8 (pp. 1-24). Hillsdale, NJ: Erlbaum. http://dspace.palermo. edu/dspace/bitstream/10226/368/1/2Psico\%2007.pdf (Erişim tarihi: 10.01.2019).

Sönmez, V. (2012). Eğitim felsefesi (11. b.), Ankara, Anı Yayıncılık.

Spranger, E. (2001). İnsan tipleri bir kişilik psikolojisi (A. Aydoğan, Çev.). İstanbul: İz.

Srite, M., \& Karahanna, E. (2006). The role of espoused national cultural values in technology acceptance. MIS Quarterly, 679-704.

Tor, H. ve Erden, O. (2004). İlköğretim öğrencilerinin bilgi teknolojilerinden yararlanma düzeyleri üzerine bir araştırma. The Turkish Online Journal of Educational Technology. $3(1), 16,120-130$.

Torero, M., \& Von Braun, J. (2006). Information and communication technologies for development and poverty reduction: The potential of telecommunications. Intl Food Policy Res Inst.

Turney, C. S. M., Robinson, D., Lee, M., \& Soutar, A. (2009). Using technology to direct learning in higher education: The way forward?. Active learning in higher education, 10(1), $71-83$.

Vannatta, R., Beyerbach, B., \& Walsh, C. (2001). From teaching technology to using technology to enhance student learning: Preservice teachers' changing perceptions of technology infusion. Journal of Technology and Teacher Education, 9(1), 105-127.

Yıldırım, A. ve Şimşek, H. (2008). Sosyal bilimlerde nitel araştırma yöntemleri (7.baskı). Ankara: Seçkin Yayıncılık.

\section{ETİK ve BİLIMSEL İLKELER SORUMLULUK BEYANI}

$\mathrm{Bu}$ çalışmanın tüm hazırlanma süreçlerinde etik kurallara ve bilimsel atıf gösterme ilkelerine riayet edildiğini yazar(lar) beyan eder. Aksi bir durumun tespiti halinde Afyon Kocatepe Üniversitesi Sosyal Bilimler Dergisi'nin hiçbir sorumluluğu olmayıp, tüm sorumluluk makale yazarlarına aittir. 